\title{
Genetic Polymorphisms and Posttraumatic Complications
}

\author{
Wei Gu${ }^{1,2}$ and Jianxin Jiang ${ }^{1}$ \\ ${ }^{1}$ State Key Laboratory of Trauma, Burns and Combined Injury, Institute of Surgery Research, Chongqing 400042, China \\ ${ }^{2}$ Research Institute of Surgery, Daping Hospital, Third Military Medical University, Daping, Chongqing 400042, China
}

Correspondence should be addressed to Wei Gu, clgwjm@163.com

Received 26 September 2010; Accepted 23 December 2010

Academic Editor: H. Heng

Copyright () 2010 W. Gu and J. Jiang. This is an open access article distributed under the Creative Commons Attribution License, which permits unrestricted use, distribution, and reproduction in any medium, provided the original work is properly cited.

\begin{abstract}
Major trauma is the leading cause of death in young adults. Despite advances in prehospital system and treatment in hospital, mortality rates have not improved significantly over the past decades. Victims of severe injuries who survive the initial hours have great risk for additional life-threatening complicaitons, including uncontrollable infection (sepsis) and multiple organ dysfunction syndrome (MODS). Single nucleotide polymorphisms (SNPs) have been shown to affect susceptibility to the course of numerous diseases. Accumulating evidence suggests that genetic backgrounds also play important roles in posttraumatic complications. Genetic polymorphisms may become powerful biomarkers for diagnosis and prognosis of trauma-induced complications. Recent advances in studies on associations between genetic polymorphisms and sepsis or MODS have led to better understanding of posttraumatic complications. Here we summarise recent findings on genetic variations in molecules of the innate immune system and other systems as well as their connection with susceptibility to posttraumatic complications.
\end{abstract}

\section{Introduction}

Major trauma is the leading cause of death in young adults and the third most common cause of death overall [1]. Advanced prehospital systems now deliver victims to hospitals where imminent threats to life, including airway compromise, hypoxia, hemorrhage, and intracranial hypertension are identified and controlled within few hours. However, victims of severe injuries who survive the initial hours have great risk for additional life-threatening complications, which include uncontrollable infection (sepsis) and multiple organ dysfunction syndrome (MODS), which remains a worldwide problem that is the leading causes of intensive care unit mortality $[2,3]$. The causes of sepsis/ MODS are numerous (e.g., age, sex, and injury), but the reasons why certain individuals develop sepsis/MODS while others following similar trauma insults do not are not well understood. There is ample evidence in the literature that gene-host and gene-environment interactions may play a large role in the morbidity and mortality associated with these complications.

Early evidence favoring a role for genetic differences in trauma outcomes from a study conducted in animal subjects.
Radojicic et al. [4] reported significant differences of their resistance to mechanical, thermal, and radiation trauma among four inbred strains of mice (AKR, BALB/c, CBA, and C57BL/6). Studies from our laboratory also showed that the mortality of C57BL/6 mice was significantly lower than $\mathrm{BALB} / \mathrm{c}$ mice after injured by blast wave [5]. In an early epidemiological study, a strong association between death from infection in adoptees and their biological, but not adoptive, parents, also suggested a genetic influence on the risk for and outcome from infection [6]. Subsequent to these initial observations, numerous studies have identified that genetic factors play an important role in the pathogenesis of complications after trauma.

Genetic variations include insertions, deletions, duplications, or single nucleotide polymorphisms (SNPs). Researchers have found that genetic polymorphisms might affect clinical phenotype by altering the function of the encoded protein, either by changing the structure of this protein or by modifying the expression of a gene. Furthermore, in contrast to protein biomarkers that may be transiently expressed during disease pathogenesis, gene polymorphisms also do not vary in response to underlying illnesses, and may be predictive indicators of disease susceptibility. Therefore, a genetic 
approach to assessing individual reaction to severe trauma is attractive since genotype can be easily determined from peripheral blood with minimal risk. Since trauma is sporadic, genetic association studies are more useful tools in investigating its possible relationships with gene polymorphisms than linkage studies. Recent advances in genotyping technologies have greatly expanded the number of studies that can test possible associations between gene polymorphisms and certain phenotypes. This paper aims to critically review evidence on the role of genetic polymorphisms in the pathogenesis of posttraumatic sepsis and MODS, based on association studies conducted primarily in human. We discuss the advantages and limitations of present studies and explore the application of microarray and other technologies to this important clinical and scientific problem.

\section{Methodology of Genetic Association Studies on Trauma}

In general, there are two approaches to perform genetic association studies: the candidate-gene approach and the genomewide approach (also known as genomewide association studies, GWAS). The completion of the HapMap project and development of high-density genomewide SNP arrays have enabled GWAS for many human complex diseases, such as Type II diabetes [7], prostate cancer [8], pulmonary sarcoidosis [9], and asthma phenotypes [10]. Unbiased GWAS have provided important insight to novel susceptibility genes for disease. However, no GWAS studies have not yet been published for complications after trauma, may be because of the expensive cost and complex etiology and multifactorial nature of trauma. In the candidate-gene approach, a few SNPs are genotyped on a gene of interest, which is chosen based on a biological hypothesis for the disease. The knowledge of the pathophysiology of sepsis and MODS has directed the search for candidate genes relevant to these clinical syndrome [11]. Genes of the pattern-recognition receptors (PRRs) system, complement system, coagulation system, cytokines, and signal-transduction molecules contribute to the list of candidate genes for sepsis and MODS that show genomic variation.

\section{Genetic Polymorphisms Assisted with Complications after Trauma}

Using the methods described above, various candidate susceptibility genes have been identified. And a number of investigations have evaluated the role of functional polymorphisms in case-control investigations. Reviewed below are some of the genes that have been investigated for association with the outcome after trauma.

\section{Pattern-Recognition Receptors System Polymorphisms}

Pattern recognition receptors have recently been discovered and a concept has arisen focusing on microbial "patterns" associated with pathogens. Numerous studies have been performed to link these receptors to disease phenotypes, including sepsis. TLRs are key cellular receptors for initiation of the inflammatory response that recognise invading microbes and are an integral component of the innate immune system $[12,13]$. Because of their importance in both the innate immune response and the induction of adaptive immunity, TLRs are currently at the centre of both basic research and drug development. Two groups of TLRs exist: one group is expressed on the surface of immune cells and recognises components of microbial cell walls such as lipopolysaccharide (LPS) of Gram-negative bacteria (TLR4) and lipopeptides (TLR2/TLR1 or TLR2/TLR6) or microbial proteins such as flagellin (TLR5) and protozoan profilin (TLR11); the other group of TLRs is expressed within the cell and recognises certain nucleic acids, such as single-stranded or double-stranded RNA (TLR7/TLR8 and TLR3, resp.), or CpG-rich DNA (TLR9) in specific cellular compartments. The relationship between gene polymorphisms in TLR1, TLR2, TLR4 and sepsis, and MODS has been well studied (Table 1). Although Arg753Thr in TLR2 gene has been shown to be associated with Gram-positive infections [14, 15], it was not existing in Chinese population. Our studies identified that another tagging SNP in TLR2 gene (19216T/C) was associated with cytokine production and seemed to confer an increased risk of sepsis and MODS after trauma [16]. We also found that $-2242 \mathrm{~T} / \mathrm{C}$ and $11367 \mathrm{G} / \mathrm{C}$ were two functional SNPs in TLR4 gene and may be related to sepsis morbidity [17-19]. There are comolecules associated with TLR4 sensing, including MD-2, CD14 and LPSbinding protein (LBP). A polymorphism in MD-2 promoter $(-1625 \mathrm{C} / \mathrm{G})$ influenced MD-2 promoter activity and expression in vitro, and showed clinical influence in sepsis after trauma [20]. Although studies regarding CD14 have gotten conflicting results, our study identified that $-159 \mathrm{C} / \mathrm{T}$ and $-1145 \mathrm{G} / \mathrm{A}$ are both related to posttraumatic complications and had synergistic effects [21]. LBP SNPs were studied as part of association studies and there were also conflicting results with regard to sepsis $[22,23]$. However, one recent cohort and functional study in our laboratory could confirm an increased risk of infection with Pro436Leu in LBP gene.

\section{Gene Polymorphisms in Signal Transduction System}

Intracellular signal transduction involves several steps, including numerous adaptor molecules and intracellular kinases. However, Gene polymorphisms in these genes were seldom studied. The Ser180Leu SNP in TIRAP/Mal gene was shown to be associated with invasive pneumococcal infection [36]. IRAK-1 1595T/C was also associated with increased risk for sepsis [35]. Two functional mutations in IRAK-4 were found in a patient with recurrent bacterial infections [34]. A study focused on NF- $\kappa \mathrm{B}$ activity in invasive pneumococcal identified two SNPs (rs3138053 and rs2233406) associated with susceptibility of infection [37], referring a key role for the transcription factor $\mathrm{NF}-\kappa \mathrm{B}$ in the host response to infection. 
TABLE 1: Effects of gene polymorphisms on sepsis or MODS.

\begin{tabular}{|c|c|c|c|c|c|c|}
\hline Gene & $\begin{array}{l}\text { Chrome } \\
\text { location }\end{array}$ & Variation & Study size & Functional effects & $\begin{array}{l}\text { Clinical effects on sepsis or } \\
\text { MODS }\end{array}$ & Reference \\
\hline \multicolumn{7}{|c|}{ Pattern-recognition receptors } \\
\hline \multirow[t]{2}{*}{ TLR1 } & \multirow[t]{2}{*}{$4 \mathrm{p} 14$} & $\begin{array}{l}-7202 \mathrm{~A} / \mathrm{G} \\
(\mathrm{rs} 5743551)\end{array}$ & 999 & $\begin{array}{l}\text { Cytokine } \\
\text { production and } \\
\text { TLR1 expression }\end{array}$ & $\begin{array}{l}\text { Sepsis, organ dysfunction and } \\
\text { death (ODD), sepsis related } \\
\text { acute lung injury (ALI) }\end{array}$ & {$[24]$} \\
\hline & & I602S & & $\begin{array}{l}\text { IL- } 6 \text { production } \\
\text { and NF- } \kappa \mathrm{B} \\
\text { signalling }\end{array}$ & & {$[25]$} \\
\hline \multirow[t]{3}{*}{ TLR2 } & \multirow[t]{3}{*}{$4 q 32$} & $-16933 \mathrm{~T} / \mathrm{A}$ & 252 & & $\begin{array}{l}\text { increased prevalence of sepsis } \\
\text { and with Gram-positive } \\
\text { bacteria }\end{array}$ & {$[15]$} \\
\hline & & Arg753Thr & 91 & $\begin{array}{l}\text { staphylococcal } \\
\text { infections }\end{array}$ & $\begin{array}{l}\text { Association with } \\
\text { Gram-positive infection }\end{array}$ & {$[14,15]$} \\
\hline & & $\begin{array}{l}19216 \mathrm{~T} / \mathrm{C} \\
(\mathrm{rs} 3804099)\end{array}$ & 410 & $\begin{array}{l}\text { Cytokine } \\
\text { production }\end{array}$ & Association with sepsis & {$[16]$} \\
\hline \multirow{4}{*}{ TLR4 } & \multirow{4}{*}{$9 q 33.1$} & $896 \mathrm{~A} / \mathrm{G}$ & 598 & & $\begin{array}{l}\text { Association with decreased } \\
\text { risk of complicated sepsis }\end{array}$ & {$[26]$} \\
\hline & & Asp299Gly, Thr399Ile & $307 / 319 / 116$ & & $\begin{array}{l}\text { sepsis; Gram-negative septic } \\
\text { shock; Conflicting results }\end{array}$ & {$[27-29]$} \\
\hline & & $-2242 \mathrm{~T} / \mathrm{C}$ & 303 & $\begin{array}{l}\text { Cytokine } \\
\text { production and } \\
\text { promoter activity }\end{array}$ & $\begin{array}{l}\text { Association with sepsis and } \\
\text { MODS }\end{array}$ & {$[17]$} \\
\hline & & $11367 \mathrm{G} / \mathrm{C}$ & 132 & gene expression & $\begin{array}{l}\text { Association with sepsis and } \\
\text { MODS }\end{array}$ & {$[18,19]$} \\
\hline LBP & $20 \mathrm{q} 11.23$ & $\begin{array}{l}\text { Cys98Gly, Pro436Leu } \\
\text { and } 1683 \mathrm{~T} / \mathrm{C}\end{array}$ & $454 / 1215$ & $\begin{array}{l}\text { higher median } \\
\text { basal serum LBP } \\
\text { levels }\end{array}$ & $\begin{array}{l}\text { Gender-specific association } \\
\text { with sepsis. Bacteraemia after } \\
\text { stem cell transplantation and } \\
\text { death from Gram-negative } \\
\text { bacteraemia }\end{array}$ & {$[22,23]$} \\
\hline CD14 & $5 q 31.1$ & $\begin{array}{l}-159 \mathrm{C} / \mathrm{T}(-260 \mathrm{C} / \mathrm{T}) \\
-1145 \mathrm{G} / \mathrm{A}\end{array}$ & $\begin{array}{l}293 / 85 / 319 / \\
116 / 252 / 430\end{array}$ & $\begin{array}{l}\text { higher monocyte } \\
\text { mCD14, but not } \\
\text { sCD14 expression }\end{array}$ & $\begin{array}{l}\text { higher mortality; higher sepsis } \\
\text { morbidity. Conflicting results }\end{array}$ & $\begin{array}{l}{[15,21} \\
28-32]\end{array}$ \\
\hline \multirow{2}{*}{$\mathrm{MD}-2$} & \multirow{2}{*}{$8 \mathrm{q} 21.11$} & $\begin{array}{l}\text { 103G/A } \\
\text { (Thr35Ala) }\end{array}$ & 20 & & $\begin{array}{l}\text { Decreased cytokine release. } \\
\text { No influence on sepsis studied }\end{array}$ & {$[33]$} \\
\hline & & $-1625 \mathrm{C} / \mathrm{G}$ & 105 & $\begin{array}{l}\text { MD-2 promoter } \\
\text { activity, MD-2 } \\
\text { expression }\end{array}$ & $\begin{array}{l}\text { Association with sepsis and } \\
\text { MODS after trauma }\end{array}$ & {$[20]$} \\
\hline \multicolumn{7}{|c|}{ Signal transduction } \\
\hline IRAK-4 & $12 \mathrm{q} 12$ & $\begin{array}{l}877 \mathrm{C} / \mathrm{T}, 620-621 / \mathrm{AC} \\
\text { deletion }\end{array}$ & 1 & $\begin{array}{l}\text { IRAK-1 kinase } \\
\text { activity }\end{array}$ & Severe infections in childhood & {$[34]$} \\
\hline IRAK-1 & $\mathrm{Xq} 28$ & 1595T/C (haplotype) & 155 & $\begin{array}{l}\text { nuclear levels of } \\
\mathrm{NF}-\kappa \mathrm{B}\end{array}$ & Increased mortality in sepsis & {$[35]$} \\
\hline TIRAP/Mal & $11 \mathrm{q} 24.2$ & $\begin{array}{l}\text { Ser180Leu } \\
(\text { rs8177374) }\end{array}$ & 6106 & & $\begin{array}{l}\text { Heterozygous carriers } \\
\text { associated with infectious } \\
\text { disease }\end{array}$ & {$[36]$} \\
\hline $\mathrm{I} \kappa \mathrm{B}$ & $14 \mathrm{q} 13$ & rs3138053, rs2233406 & 1060 & & $\begin{array}{l}\text { Association with invasive } \\
\text { pneumococcal }\end{array}$ & {$[37]$} \\
\hline \multicolumn{7}{|c|}{ Cytokines } \\
\hline IL- $1 \alpha$ & $2 q 14$ & 46 bp VNTR & & & No association with sepsis & {$[38]$} \\
\hline IL- $1 \beta$ & $2 \mathrm{q} 14$ & $-31 \mathrm{C} / \mathrm{T},-511 \mathrm{C} / \mathrm{T}$ & $60 / 276 / 238$ & $\begin{array}{l}\text { Higher production } \\
\text { of IL- } 1 \beta\end{array}$ & $\begin{array}{l}\text { Association with sepsis; } \\
\text { Higher mortality in } \\
\text { homozygous carriers with } \\
\text { meningococcal sepsis. } \\
\text { Conflicting results }\end{array}$ & {$[38-41]$} \\
\hline
\end{tabular}


Table 1: Continued.

\begin{tabular}{|c|c|c|c|c|c|c|}
\hline Gene & $\begin{array}{l}\text { Chrome } \\
\text { location }\end{array}$ & Variation & Study size & Functional effects & $\begin{array}{l}\text { Clinical effects on sepsis or } \\
\text { MODS }\end{array}$ & Reference \\
\hline IL-1RN & $2 \mathrm{q} 14.2$ & intron 2, VNTR & 78 & & $\begin{array}{l}\text { Higher mortality in } \\
\text { homozygous carriers }\end{array}$ & {$[38,42]$} \\
\hline \multirow{2}{*}{ IL-6 } & \multirow{2}{*}{$7 \mathrm{p} 21$} & $-174 \mathrm{G} / \mathrm{C}$ & $69 / 288 / 293$ & $\begin{array}{l}\text { Baseline of } \\
\text { C-reactive protein }\end{array}$ & $\begin{array}{l}\text { C-allele confers increased risk } \\
\text { of shock }\end{array}$ & $\begin{array}{c}{[30,43-} \\
45]\end{array}$ \\
\hline & & $-572 \mathrm{C} / \mathrm{G}$ & 453 & $\begin{array}{l}\text { IL-6 production } \\
\text { from leukocytes } \\
\text { after LPS ex vivo }\end{array}$ & $\begin{array}{l}\text { Sepsis in major trauma } \\
\text { patients }\end{array}$ & {$[46]$} \\
\hline IL-10 & $1 q 31-32$ & $\begin{array}{l}-592 \mathrm{C} / 734 \mathrm{G} / 3367 \mathrm{G} \\
-1082 \mathrm{G} / \mathrm{A}\end{array}$ & $550 / 33$ & $\begin{array}{l}\text { interleukin-10 } \\
\text { production }\end{array}$ & $\begin{array}{l}\text { Association with sepsis from } \\
\text { pneumonia, increased } \\
\text { mortality in severe sepsis }\end{array}$ & {$[47-51]$} \\
\hline $\mathrm{TNF} \alpha$ & $6 \mathrm{p} 21.3$ & $-308 \mathrm{G} / \mathrm{A}$ & $1321 / 197$ & & $\begin{array}{l}\text { Association not clear. Early } \\
\text { studies suggest higher risk } \\
\text { when homozygous }\end{array}$ & {$[52-60]$} \\
\hline $\mathrm{TNF} \beta$ & $6 \mathrm{p} 21.3$ & & & & Association not clear & {$[56]$} \\
\hline IFN- $\gamma$ & $12 \mathrm{q} 14$ & CA repeat & 61 & & Association with sepsis & {$[61]$} \\
\hline MIF & $22 \mathrm{q} 11.23$ & $\begin{array}{l}-173 \mathrm{G} / \mathrm{C},-794 \\
\text { CATT repeat }\end{array}$ & & $\begin{array}{l}\text { MIF RNA and } \\
\text { protein levels from } \\
\text { mononuclear cells } \\
\text { stimulated with } \\
\text { bacteria }\end{array}$ & $\begin{array}{l}\text { Influence on sepsis in } \\
\text { African-Americans }\end{array}$ & {$[62]$} \\
\hline & & & Coagulatic & tem & & \\
\hline PAI-1 & $7 \mathrm{q} 21.3-\mathrm{q} 22$ & $4 \mathrm{G} / 5 \mathrm{G}$ & 50 & $\begin{array}{l}\text { Increased gene } \\
\text { transcription in } \\
\text { cell lines in vitro } \\
\text { and with increased } \\
\text { PAI-1 } \\
\text { concentrations in } \\
\text { carriers in vivo }\end{array}$ & $\begin{array}{l}\text { Higher rate of septic shock in } \\
\text { meningitis }\end{array}$ & {$[63]$} \\
\hline TAFI & $13 q 14.11$ & Thr325Ile & 50 & & $\begin{array}{l}\text { Higher risk of death in } \\
\text { meningitis }\end{array}$ & {$[64]$} \\
\hline Factor V & $1 \mathrm{q} 23$ & R506Q & 3894 & & $\begin{array}{l}\text { Smaller risk of sepsis } \\
\text { (heterozygous) }\end{array}$ & {$[65]$} \\
\hline Fibrinogen & $4 \mathrm{q} 28$ & $\begin{array}{l}-854 \mathrm{G} / \mathrm{A},-455 \mathrm{G} / \mathrm{A}, \\
\text { and }+9006 \mathrm{G} / \mathrm{A} . \\
-148 \mathrm{C} / \mathrm{T}\end{array}$ & $631 / 73$ & $\begin{array}{l}\text { higher fibrinogen } \\
\text { levels }\end{array}$ & $\begin{array}{l}\text { Haplotype GAA was } \\
\text { associated with a significantly } \\
\text { lower } 28 \text {-day mortality }\end{array}$ & {$[66,67]$} \\
\hline
\end{tabular}

\section{Cytokine Polymorphisms}

During sepsis, there is a full-blown, systemic activation of immune responses. As a result, sepsis is accompanied by a markedly imbalanced cytokine response (known as a "cytokine storm"), which converts responses that are normally beneficial for fighting infections into excessive, damaging inflammation. As effectors, cytokines released from immunocompetent cells play major role in the inflammatory response to infection. As a result, a number of variations in cytokine genes have been reported in gene association studies.

TNF $\alpha$ is a prototypical proinflammatory cytokine. The relationship between TNF $\alpha /-308$ SNP and sepsis has been studied extensively. An association with sepsis severity and outcome following different inflammatory insults was found repeatedly, with a tendency towards increasing levels of $\mathrm{TNF} \alpha$ and therefore a stronger inflammatory response [52-54]. However, these results have not been confirmed in other studies $[55,56]$. Another important proinflammatory cytokine is interleukin (IL)-1 (isoforms $\alpha$ and $\beta$ ). An IL- $1 \alpha$ polymorphisms was described for intron 6 ("variable number tandem repeats", $46 \mathrm{bp}$ ) but this variation of IL- $1 \alpha$ failed to show an association with sepsis [38]. However, our study found that polymorphisms in the IL- $1 \beta$ gene was associated with worse outcome in severe trauma patients $[39,40]$. Besides these, polymorphisms in other cytokine genes, including IL-6, IL-10, TNF $\alpha, \operatorname{TNF} \beta$, IFN- $\gamma$, and MIF were studied (Table 1). Since these genes are form crosstalks in the pathogenesis of sepsis, we further studied the synergetic effects of 13 SNPs in 9 cytokines and found that polymorphisms of IL-1 $\beta /-1470$, IL- $1 \beta /-511$, IL-1 $\beta /-31$, 
IL-4/-589, IL-6/-572, IL-8/-251, IL-10/-819, and TNF $\alpha /-308$ are susceptibility loci for the development of sepsis and organ dysfunction in major trauma patients. Patients with more than four risk alleles of the eight SNPs had more than 50\% sepsis morbidity and more severe organ dysfunction [68].

\section{Coagulation System Polymorphisms}

In the clinical setting of sepsis, dysregulation of the coagulation cascade results in major complications [69]. The extent of activation of the coagulation cascade during sepsis can range from an insignificant level to the occurrence of disseminated intravascular coagulation (DIC). Therefore, inherited variations associated with infections and sepsis have been described for coagulation factors such as plasminogen activator inhibitor-1 (PAI-1), thrombinactivatable fibrinolysis inhibitor (TAFI), fibrinogen, and factor 5 (Table 1). Studies on genetic variation in PAI-1 have been associated with morbidity of septic shock in meningitis patients [63]. For Thr325Ile in the TAFI gene, the outcome for meningitis was negatively influenced in homozygous carriers [64]. Furthermore, a protective haplotype GAA has been described in fibrinogen gene [66]. For Factor V/R506Q, the heterozygous carriers have smaller risk of sepsis [65].

\section{Future Directions}

Trauma is the forth major reason of morbidity and mortality all over the world, with associated great societal costs every year. The prevention and treatment of injury-induced sepsis and MODS are an international priority. It is not difficult to predict that the number of genetic studies concerning complications after major trauma will continue to increase. At the same time, platforms for genetic sequencing and expression analysis, as well as international databases such as HapMap, have been greatly improved in recent years. It will certainly facilitate genetic synchrony of genotypic and phenotypic data using enormous numbers of trauma patients.

Although ongoing hypothesis-testing approaches will continue to bring important insights, they might be limited in their ability to provide a coherent, integrated view of genetic background in trauma patients. GWAS has been suggested as a potential powerful tool for future genetic predisposition studies. However, we emphasise that this systematic, whole-genome approach, that always ignores important information due to low power, must complement, not replace, the traditional single-gene approach.

Taking into account the complexity of the pathogenesis of posttraumatic complications, we and others seek to interfere the synergetic effects of polymorphisms in mutiple genes and better comprehend the pathophysiology of multiple interactions in sepsis and MODS after trauma. With genotyping techniques becoming more and more advanced and with the cost decreasing, larger sample studies from multiple centers in the future may lead to a clearer picture of the individual variation in response patterns leading to a change in susceptibility of complications after trauma.

\section{Acknowledgments}

This work is supported by the National Natural Science Funds for Distinguished Young Scholar (30901416) and the Project from State Key Laboratory of Trauma, Burns and Combined Injury (no. SKLZZ200815).

\section{References}

[1] E. J. Mackenzie, "Epidemiology of injuries: current trends and future challenges," Epidemiologic Reviews, vol. 22, no. 1, pp. 112-119, 2000.

[2] R. P. Dellinger, M. M. Levy, J. M. Carlet et al., "Surviving sepsis campaign: international guidelines for management of severe sepsis and septic shock: 2008," Critical Care Medicine, vol. 36, no. 1, pp. 296-327, 2008.

[3] Z. Lausevic, M. Lausevic, J. Trbojevic-Stankovic, S. Krstic, and B. Stojimirovic, "Predicting multiple organ failure in patients with severe trauma," Canadian Journal of Surgery, vol. 51, no. 2, pp. 97-102, 2008.

[4] C. Radojicic, B. Andric, M. Simovic, A. Dujic, and D. Marinkovic, "Genetic basis of resistance to trauma in inbred strains of mice," Journal of Trauma, vol. 30, no. 2, pp. 211-213, 1990.

[5] G. Feng, Z. Wang, Z. Yang et al., "Preliminary study on posttrauma-response heterogeneity between $\mathrm{c} 57 \mathrm{bl} / 6$ and balb/ c inbred mice," Chinese Journal of Traumatology, vol. 5, pp. 301-303, 2001.

[6] T. I. A. Sorensen, G. G. Nielsen, P. K. Andersen, and T. W. Teasdale, "Genetic and environmental influences on premature death in adult adoptees," New England Journal of Medicine, vol. 318, no. 12, pp. 727-732, 1988.

[7] J. Gudmundsson, P. Sulem, V. Steinthorsdottir et al., "Two variants on chromosome 17 confer prostate cancer risk, and the one in TCF2 protects against type 2 diabetes," Nature Genetics, vol. 39, no. 8, pp. 977-983, 2007.

[8] J. Gudmundsson, P. Sulem, A. Manolescu et al., "Genomewide association study identifies a second prostate cancer susceptibility variant at 8q24," Nature Genetics, vol. 39, no. 5, pp. 631-637, 2007.

[9] S. Hofmann, A. Franke, A. Fischer et al., "Genome-wide association study identifies ANXA11 as a new susceptibility locus for sarcoidosis," Nature Genetics, vol. 40, no. 9, pp. 11031106, 2008.

[10] S. Weidinger, C. Gieger, E. Rodriguez et al., "Genome-wide scan on total serum IgE levels identifies FCER1A as novel susceptibility locus," PLoS Genetics, vol. 4, no. 8, Article ID e1000166, 2008.

[11] D. Rittirsch, M. A. Flierl, and P. A. Ward, "Harmful molecular mechanisms in sepsis," Nature Reviews Immunology, vol. 8, no. 10, pp. 776-787, 2008.

[12] B. Beutler, "Innate immunity: an overview," Molecular Immunology, vol. 40, no. 12, pp. 845-859, 2004.

[13] R. Medzhitov, "Recognition of microorganisms and activation of the immune response," Nature, vol. 449, no. 7164, pp. 819826, 2007.

[14] E. Lorenz, J. P. Mira, K. L. Cornish, N. C. Arbour, and D. A. Schwartz, "A novel polymorphism in the toll-like receptor 2 gene and its potential association with staphylococcal infection," Infection and Immunity, vol. 68, no. 11, pp. 63986401, 2000.

[15] A. M. Sutherland, K. R. Walley, and J. A. Russell, "Polymorphisms in CD14, mannose-binding lectin, and Toll-like 
receptor-2 are associated with increased prevalence of infection in critically ill adults," Critical Care Medicine, vol. 33, no. 3, pp. 638-644, 2005.

[16] K. H. Chen, W. Gu, L. Zeng et al., "Identification of haplotype tag snps within the entire TLR2 gene and their clinical relevance in patients with major trauma," Shock, vol. 35, no. 1, pp. 35-41, 2011.

[17] K. Chen, Y. T. Wang, W. Gu et al., "Functional significance of the toll-like receptor 4 promoter gene polymorphisms in the Chinese Han population," Critical Care Medicine, vol. 38, no. 5, pp. 1292-1299, 2010.

[18] Z. X. Duan, W. Gu, L. Y. Zhang et al., "Clinical relevance of the TLR4 11367 polymorphism in patients with major trauma," Archives of Surgery, vol. 144, no. 12, pp. 1144-1148, 2009.

[19] Z. X. Duan, P. F. Zhu, H. Dong et al., "Functional significance of the TLR4/11367 polymorphism identified in Chinese Han population," Shock, vol. 28, no. 2, pp. 160-164, 2007.

[20] W. Gu, Y. A. Shan, J. Zhou et al., "Functional significance of gene polymorphisms in the promoter of myeloid differentiation-2," Annals of Surgery, vol. 246, no. 1, pp. 151$158,2007$.

[21] W. Gu, H. Dong, D. P. Jiang et al., "Functional significance of CD14 promoter polymorphisms and their clinical relevance in a Chinese Han population," Critical Care Medicine, vol. 36, no. 8, pp. 2274-2280, 2008.

[22] J. A. Hubacek, F. Stüber, D. Fröhlich et al., "Gene variants of the bactericidal/permeability increasing protein and lipopolysaccharide binding protein in sepsis patients: genderspecific genetic predisposition to sepsis," Critical Care Medicine, vol. 29, no. 3, pp. 557-561, 2001.

[23] J. W. Chien, M. J. Boeckh, J. A. Hansen, and J. G. Clark, "Lipopolysaccharide binding protein promoter variants influence the risk for Gram-negative bacteremia and mortality after allogeneic hematopoietic cell transplantation," Blood, vol. 111, no. 4, pp. 2462-2469, 2008.

[24] M. M. Wurfel, A. C. Gordon, T. D. Holden et al., "Toll-like receptor 1 polymorphisms affect innate immune responses and outcomes in sepsis," American Journal of Respiratory and Critical Care Medicine, vol. 178, no. 7, pp. 710-720, 2008.

[25] T. R. Hawn, E. A. Misch, S. J. Dunstan et al., "A common human TLR1 polymorphism regulates the innate immune response to lipopeptides," European Journal of Immunology, vol. 37, no. 8, pp. 2280-2289, 2007.

[26] S. Shalhub, C. E. Junker, S. D. Imahara, M. N. Mindrinos, S. Dissanaike, and G. E. O'keefe, "Variation in the TLR4 gene influences the risk of organ failure and shock posttrauma: a cohort study," Journal of Trauma, vol. 66, no. 1, pp. 115-122, 2009.

[27] C. Feterowski, K. Emmanuilidis, T. Miethke et al., "Effects of functional toll-like receptor- 4 mutations on the immune response to human and experimental sepsis," Immunology, vol. 109, no. 3, pp. 426-431, 2003.

[28] K. Jessen, S. Lindboe, A. Petersen, J. Eugen-Olsen, and T. Benfield, "Common TNF- $\alpha$, IL- $1 \beta$, PAI-1, uPA, CD14 and TLR4 polymorphisms are not associated with disease severity or outcome from Gram negative sepsis," BMC Infectious Diseases, vol. 7, article no. 108, 2007.

[29] D. M. Agnese, J. E. Calvano, S. J. Hahm et al., "Human tolllike receptor 4 mutations but not CD14 polymorphisms are associated with an increased risk of gram-negative infections," Journal of Infectious Diseases, vol. 186, no. 10, pp. 1522-1525, 2002.

[30] R. J. Baier, J. Loggins, and K. Yanamandra, "IL-10, IL-6 and CD14 polymorphisms and sepsis outcome in ventilated very low birth weight infants," BMC Medicine, vol. 4, article no. 10, 2006.

[31] B. B. de Aguiar, I. Girardi, D. D. Paskulin et al., "CD14 expression in the first $24 \mathrm{~h}$ of sepsis: effect of $-260 \mathrm{C}>\mathrm{T}$ CD14 SNP," Immunological Investigations, vol. 37, no. 8, pp. 752-769, 2008.

[32] L. C. D’Avila, M. H. Albarus, C. R. Franco et al., "Effect of CD14 -260C $>$ T polymorphism on the mortality of critically ill patients," Immunology and Cell Biology, vol. 84, no. 4, pp. 342-348, 2006.

[33] L. Hamann, O. Kumpf, M. Müller et al., "A coding mutation within the first exon of the human MD-2 gene results in decreased lipopolysaccharide-induced signaling," Genes and Immunity, vol. 5, no. 4, pp. 283-288, 2004.

[34] A. E. Medvedev, A. Lentschat, D. B. Kuhns et al., "Distinct mutations in IRAK-4 confer hyporesponsiveness to lipopolysaccharide and interleukin-1 in a patient with recurrent bacterial infections," Journal of Experimental Medicine, vol. 198, no. 4, pp. 521-531, 2003.

[35] J. Arcaroli, E. Silva, J. P. Maloney et al., "Variant IRAK1 haplotype is associated with increased nuclear factor- $\kappa \mathrm{B}$ activation and worse outcomes in sepsis," American Journal of Respiratory and Critical Care Medicine, vol. 173, no. 12, pp. 1335-1341, 2006.

[36] C. C. Khor, S. J. Chapman, F. O. Vannberg et al., "A Mal functional variant is associated with protection against invasive pneumococcal disease, bacteremia, malaria and tuberculosis," Nature Genetics, vol. 39, no. 4, pp. 523-528, 2007.

[37] S. J. Chapman, C. C. Khor, F. O. Vannberg et al., "I $\kappa \mathrm{B}$ genetic polymorphisms and invasive pneumococcal disease," American Journal of Respiratory and Critical Care Medicine, vol. 176, no. 2, pp. 181-187, 2007.

[38] P. Ma, D. Chen, J. Pan, and B. Du, "Genomic polymorphism within interleukin-1 family cytokines influences the outcome of septic patients," Critical Care Medicine, vol. 30, no. 5, pp. 1046-1050, 2002.

[39] A. Q. Wen, W. Gu, J. Wang et al., "Clinical relevance of IL$1 \beta$ promoter polymorphisms $(-1470,-511$, and -31$)$ in patients with major trauma," Shock, vol. 33, no. 6, pp. 576-582, 2010.

[40] AI. Q. Wen, J. Wang, K. Feng, P. F. Zhu, and J. X. Jiang, "Analysis of polymorphisms in the promoter region of interleukin- $1 \beta$ by restriction fragment length polymorphism-PCR," Chinese Journal of Traumatology, vol. 7, no. 5, pp. 271-274, 2004.

[41] R. C. Read, N. J. Camp, F. S. di Giovine et al., "An interleukin1 genotype is associated with fatal outcome of meningococcal disease," Journal of Infectious Diseases, vol. 182, no. 5, pp. 1557-1560, 2000.

[42] F. Arnalich, D. López-Maderuelo, R. Codoceo et al., "Interleukin-1 receptor antagonist gene polymorphism and mortality in patients with severe sepsis," Clinical and Experimental Immunology, vol. 127, no. 2, pp. 331-336, 2002.

[43] M. A. Vickers, F. R. Green, C. Terry et al., "Genotype at a promoter polymorphism of the interleukin-6 gene is associated with baseline levels of plasma C-reactive protein," Cardiovascular Research, vol. 53, no. 4, pp. 1029-1034, 2002.

[44] J. J. W. Tischendorf, E. Yagmur, D. Scholten et al., "The interleukin-6 (IL6)-174 G/C promoter genotype is associated with the presence of septic shock and the ex vivo secretion of IL6," International Journal of Immunogenetics, vol. 34, no. 6, pp. 413-418, 2007.

[45] B. Schlüter, C. Raufhake, M. Erren et al., "Effect of the interleukin-6 promoter polymorphism $(-174 \mathrm{G} / \mathrm{C})$ on the incidence and outcome of sepsis," Critical Care Medicine, vol. 30 , no. 1 , pp. 32-37, 2002. 
[46] W. Gu, D. Y. Du, J. Huang et al., "Identification of interleukin6 promoter polymorphisms in the Chinese Han population and their functional significance," Critical Care Medicine, vol. 36, no. 5, pp. 1437-1443, 2008.

[47] A. Wattanathum, S. Manocha, H. Groshaus, J. A. Russell, and K. R. Walley, "Interleukin-10 haplotype associated with increased mortality in critically ill patients with sepsis from pneumonia but not in patients with extrapulmonary sepsis," Chest, vol. 128, no. 3, pp. 1690-1698, 2005.

[48] S. A. Stanilova, L. D. Miteva, Z. T. Karakolev, and C. S. Stefanov, "Interleukin-10-1082 promoter polymorphism in association with cytokine production and sepsis susceptibility," Intensive Care Medicine, vol. 32, no. 2, pp. 260-266, 2006.

[49] Q. Shu, X. Fang, Q. Chen, and F. Stuber, "IL-10 polymorphism is associated with increased incidence of severe sepsis," Chinese Medical Journal, vol. 116, no. 11, pp. 1756-1759, 2003.

[50] L. Zeng, W. Gu, K. Chen et al., "Clinical relevance of the interleukin 10 promoter polymorphisms in Chinese Han patients with major trauma: genetic association studies," Critical Care, vol. 13, no. 6, p. R188, 2009.

[51] P. M. Gallagher, G. Lowe, T. Fitzgerald et al., "Association of IL-10 polymorphism with severity of illness in community acquired pneumonia," Thorax, vol. 58, no. 2, pp. 154-156, 2003.

[52] R. C. Read, D. M. Teare, A. C. Pridmore et al., "The tumor necrosis factor polymorphism TNF $(-308)$ is associated with susceptibility to meningococcal sepsis, but not with lethality," Critical Care Medicine, vol. 37, no. 4, pp. 1237-1243, 2009.

[53] K. Azim, R. McManus, K. Brophy, A. Ryan, D. Kelleher, and J. V. Reynolds, "Genetic polymorphisms and the risk of infection following esophagectomy. Positive association with TNF- $\alpha$ gene -308 genotype," Annals of Surgery, vol. 246, no. 1, pp. 122-128, 2007.

[54] R. C. Barber, C. C. Aragaki, F. A. Rivera-Chavez, G. F. Purdue, J. L. Hunt, and J. W. Horton, "TLR4 and TNF- $\alpha$ polymorphisms are associated with an increased risk for severe sepsis following burn injury," Journal of Medical Genetics, vol. 41, no. 11, pp. 808-813, 2004.

[55] F. M. Kovar, C. Marsik, T. Cvitko, O. F. Wagner, B. Jilma, and G. Endler, "The tumor necrosis factor $\alpha-308$ G/A polymorphism does not influence inflammation and coagulation response in human endotoxemia," Shock, vol. 27, no. 3, pp. 238-241, 2007.

[56] A. C. Gordon, A. L. Lagan, E. Aganna et al., “TNF and TNFR polymorphisms in severe sepsis and septic shock: a prospective multicentre study," Genes and Immunity, vol. 5, no. 8, pp. 631640, 2004.

[57] T. A. Nakada, H. Hirasawa, S. Oda et al., "Influence of toll-like receptor 4, CD14, tumor necrosis factor, and interleukine-10 gene polymorphisms on clinical outcome in Japanese critically ill patients," Journal of Surgical Research, vol. 129, no. 2, pp. 322-328, 2005.

[58] S. Shalhub, T. N. Pham, N. S. Gibran, and G. E. O'Keefe, "Tumor necrosis factor gene variation and the bisk of mortality after burn injury: a cohort study," Journal of Burn Care and Research, vol. 30, no. 1, pp. 105-111, 2009.

[59] A. C. Schueller, A. Heep, E. Kattner et al., "Prevalence of two tumor necrosis factor gene polymorphisms in premature infants with early onset sepsis," Biology of the Neonate, vol. 90, no. 4, pp. 229-232, 2006.

[60] J. P. Mira, A. Cariou, F. Grall et al., "Association of TNF2, a TNF- $\alpha$ promoter polymorphism, with septic shock susceptibility and mortality: a multicenter study," Journal of the
American Medical Association, vol. 282, no. 6, pp. 561-568, 1999.

[61] N. A. Stassen, L. A. Leslie-Norfleet, A. M. Robertson, M. R. Eichenberger, and H. C. Polk Jr., "Interferon- $\gamma$ gene polymorphisms and the development of sepsis in patients with trauma," Surgery, vol. 132, no. 2, pp. 289-292, 2002.

[62] S. E. L. Temple, K. Y. Cheong, P. Price, and G. W. Waterer, "The microsatellite, macrophage migration inhibitory factor -794, may influence gene expression in human mononuclear cells stimulated with E. coli or S. pneumoniae," International Journal of Immunogenetics, vol. 35, no. 4-5, pp. 309-316, 2008.

[63] R. G. J. Westendorp, J. J. Hottenga, and P. E. Slagboom, "Variation in plasminogen-activator-inhibitor-1 gene and risk of meningococcal septic shock," Lancet, vol. 354, no. 9178, pp. 561-563, 1999.

[64] J. A. Kremer Hovinga, R. F. Franco, M. A. Zago, H. ten Cate, R. G. J. Westendorp, and P. H. Reitsma, "A functional single nucleotide polymorphisms in the thrombin-activatable fibrinolysis inhibitor (TAFI) gene associates with outcome of meningococcal disease," Journal of Thrombosis and Haemostasis, vol. 2, no. 1, pp. 54-57, 2004.

[65] S. B. Yan and D. R. Nelson, "Effect of factor V Leiden polymorphism in severe sepsis and on treatment with recombinant human activated protein C," Critical care medicine, vol. 32, no. 5, pp. S239-S246, 2004.

[66] S. Manocha, J. A. Russell, A. M. Sutherland, A. Wattanathum, and K. R. Walley, "Fibrinogen-beta gene haplotype is associated with mortality in sepsis," Journal of Infection, vol. 54, no. 6, pp. 572-577, 2007.

[67] F. M. Kovar, C. Marsik, B. Jilma et al., "The fibrinogen $148 \mathrm{C} / \mathrm{T}$ polymorphism influences inflammatory response in experimental endotoxemia in vivo," Thrombosis Research, vol. 120, no. 5, pp. 727-731, 2007.

[68] W. Gu, L. Zeng, J. Zhou et al., "Clinical relevance of 13 cytokine gene polymorphisms in Chinese major trauma patients," Intensive Care Medicine, vol. 36, no. 7, pp. 12611265, 2010.

[69] M. Levi, E. de Jonge, T. van der Poll, and H. ten Cate, "Disseminated intravascular coagulation," Thrombosis and Haemostasis, vol. 82, no. 2, pp. 695-705, 1999. 

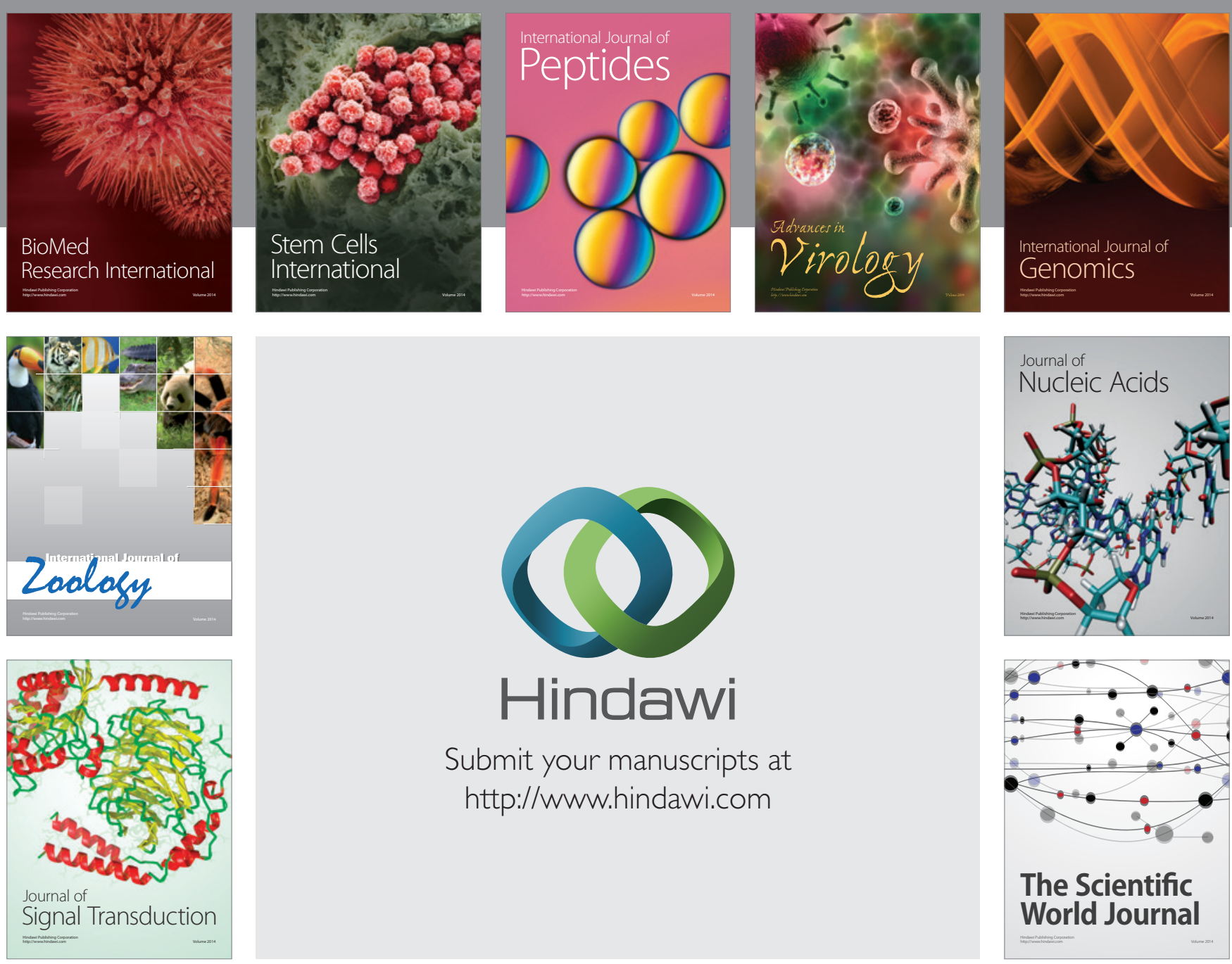

Submit your manuscripts at

http://www.hindawi.com
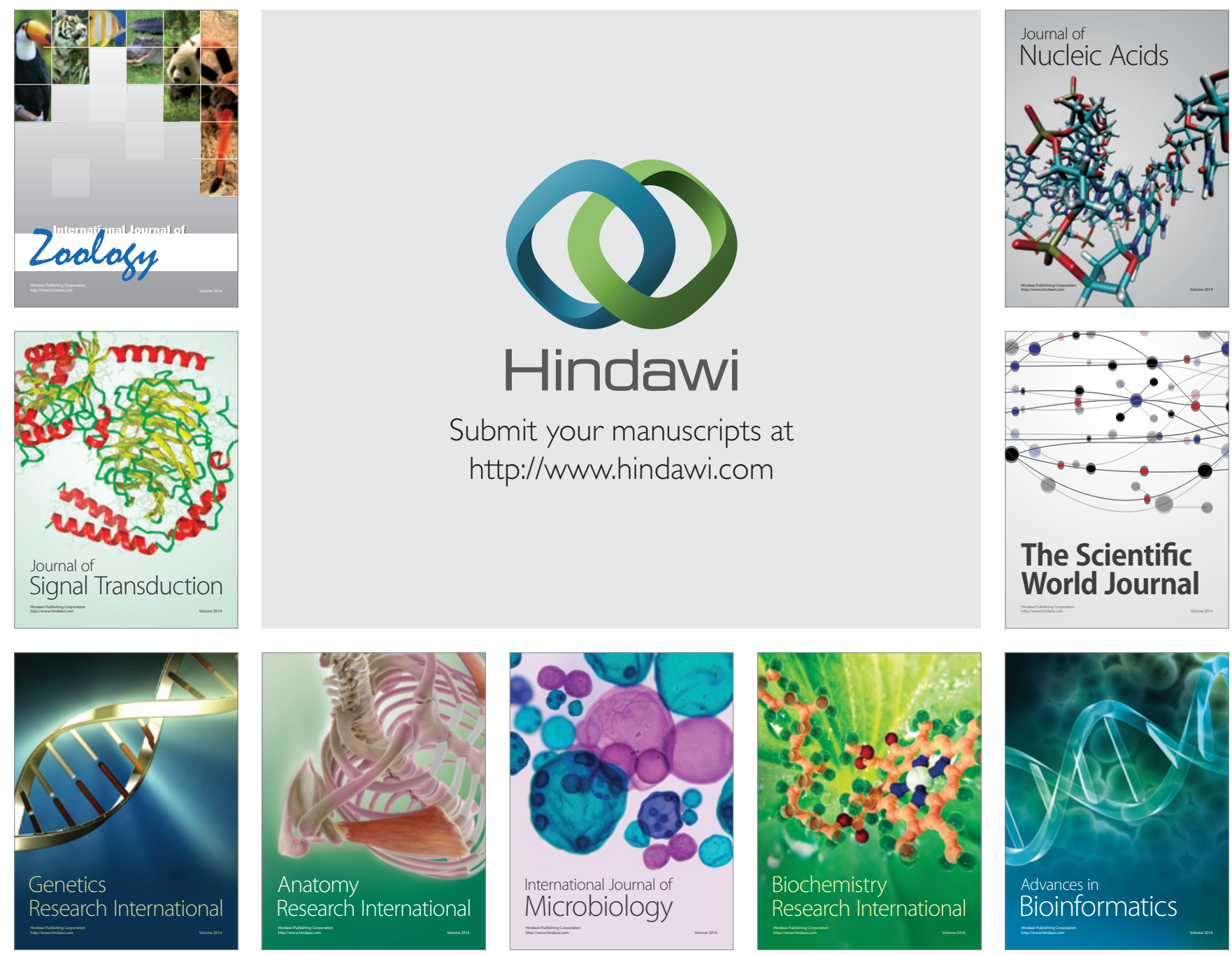

The Scientific World Journal
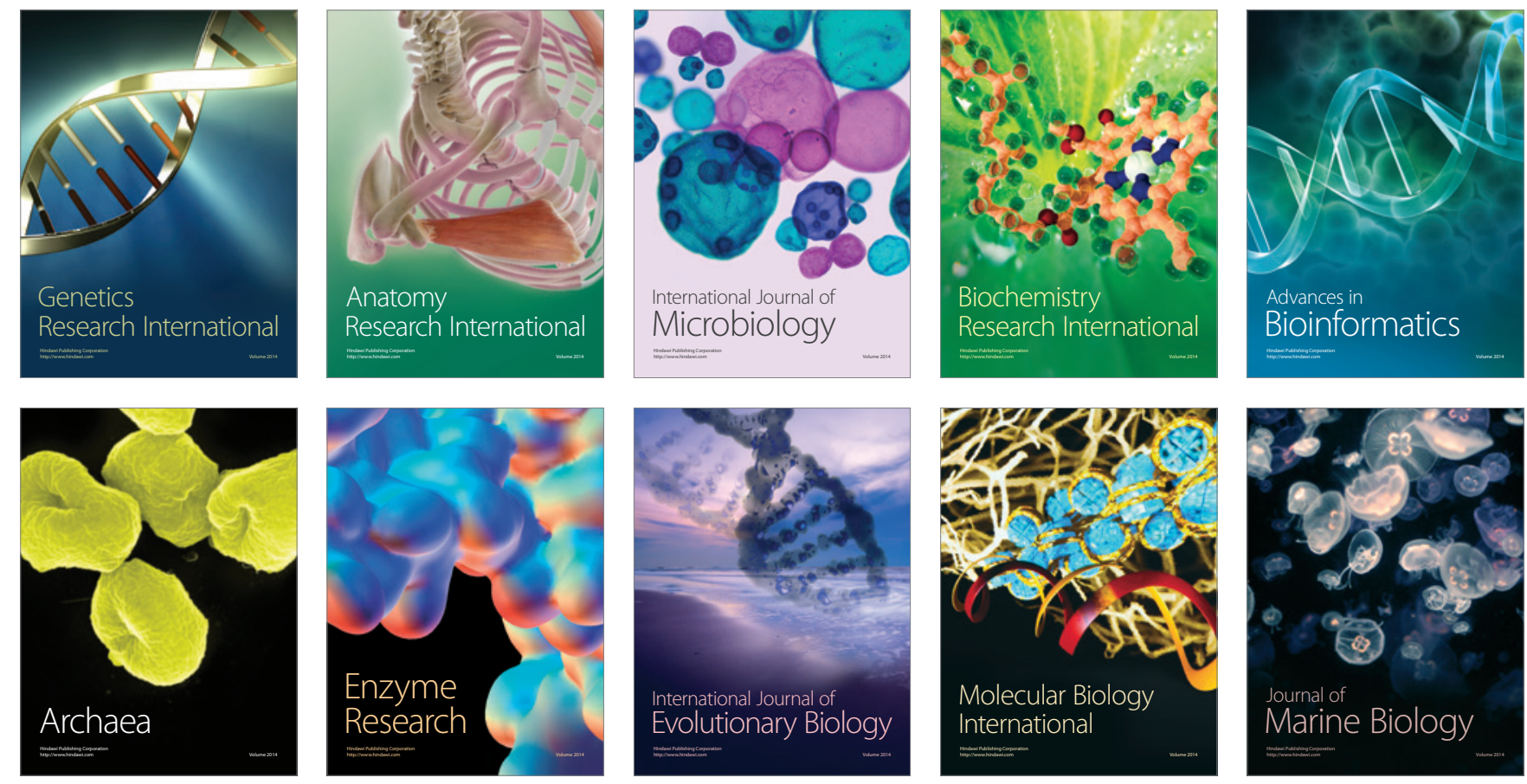